\title{
EXPLORE
}

\section{Analisis Penerapan Metode Simple Additive Weighting (SAW) Pemilihan Tanaman Hias}

\author{
Erlangga, Yolandari, Taqwan Thamrin, Ayu Kartika Puspa \\ Program Studi Sistem Informasi, Fakultas Ilmu Komputer, \\ Universitas Bandar Lampung \\ Bandar Lampung, Indonesia
}

erlangga@ubl.ac.id, yolandari.18411011@student.ubl.ac.id, taqwanthamrin@ubl.ac.id, ayukartikapuspa@ubl.ac.id

\begin{abstract}
Ornamental plants are all forms of plants that have a beautiful value, high appeal to every enthusiast. In determining the choice of ornamental plants desired, the following criteria are needed, namely: type of plant, plant price, plant age, plant size, and full distance. Manual decision-making systems are less effective in assisting the process of selecting the desired ornamental plants, and in finding recommendations for their choices. In addition, it is a factor in decreasing income for business actors because of the Covid-19 epidemic. Therefore, we need a decision support system for the selection of ornamental plants. This system uses Simple Additive Weighting (SAW) method which has the ability to solve problems from determining several criteria so that it can produce a ranking to get a choice of shop recommendations from each desired alternative.
\end{abstract}

Keywords: Ornamental Plants, Decision Support Systems, SAW Method.

\begin{abstract}
Abstrak- Tanaman hias adalah segala bentuk jenis tanaman yang memiliki nilai indah, daya tarik yang tinggi bagi setiap para peminatnya. Dalam menentukan pilihan tanaman hias yang diinginkan dibutuhkan kriteria sebagai berikut yaitu: jenis tanaman, harga tanaman, umur tanaman, ukuran tanaman, dan jarak tempuh. Sistem dalam pengambilan keputusan yang masih manual kurang efektif dalam membantu proses penentuan pilihan tanaman hias yang diinginkan, dan dalam menemukan rekomendasi atas pilihannya. Selain itu menjadi faktor menurunya pendapatan pelaku usaha karena pademi Covid-19. Oleh karena itu diperlukan suatu sistem pendukung keputusan untuk pemilihan tanaman hias. Sistem ini menggunakan pembobotan dengan metode Simple Additive Weighting (SAW) yang memiliki kemampuan dalam menyelesaikan masalah dari penentuan beberapa kriteria sehingga dapat menghasilkan rangking untuk mendapatkan pilihan rekomendasi toko dari setiap alternatif yang diinginkan.
\end{abstract}

Kata Kunci: Tanaman Hias, Sistem Pendukung Keputusan, Metode SAW.

\section{Pendahuluan}

Tanaman hias adalah semua jenis tanaman yang memiliki nilai keindahan dan daya tarik yang tinggi bagi setiap peminatnya, juga mempunyai nilai ekonomis dalam penataan, penanaman dan hiasan untuk mempercantik ruangan baik di dalam maupun diluar ruangan. Karena mengandung unsur ekonomi maka tanaman hias dapat menjadi usaha dan peluang bisnis yang sangat menjanjikan. Seiring dengan perkembangannya tanaman hias diartikan sebagai segala bentuk jenis tanaman yang memiliki nilai hias, bisa dilihat dari bunga, batang, cabang, daun, akar, dan aromanya yang menimbulkan kesan indah dan seni [1]. Internet menjadi penunjang terbesar dalam mempermudah kegiatan manusia dan terhubung dengan jaringan komunikasi seiring dengan meningkatnya kemajuan teknologi saat ini. Salah satunya di bidang pemasaran dimana semua prosesnya sudah dilakukan dengan cara online sehingga mampu bersaing dengan kecanggihan teknologi [2]. Untuk mencapai efektivitas dalam pemasaran dibutuhkan yang namanya E-marketing atau disebut pemasaran elektronik yang dapat memberikan kemudahan bagi perusahaan dan pelanggan [3].

Banyaknya peminat atau pencinta tanaman hias memberi prospek yang baik bagi masa depan para petani atau pelaku usaha khususnya di wilayah Kabupaten Tanggamus, Provinsi Lampung Indonesia. Terdapat banyak sekali macam-macam tanaman hias yang sedang popular saat ini, mulai dari jenis Philodendron, Monstera, Aglonema, Caladium, dan Anggrek. Tetapi dalam proses pemilihan tanaman hias masih dilakukan secara manual. Belum ada sistem yang sudah terkomputerisasi dalam menentukan pengambilan keputusan untuk rekomendasi toko sesuai dengan alternatif yang dicari. Minimnya informasi mengenai jarak tempuh yang jauh menjadi faktor paling mempengaruhi dari segi jangkauan pelanggan dalam menentukan pilihan saat ingin membeli tanaman secara langsung. Kemudian pada kondisi dunia yang sedang tertimpa kasus pandemic Covid-19 salah 
satunya Indonesia menyebabkan banyak masyarakat yang mulai menyukai tanaman hias dan menjadikannya hobby atau kegiatan beraktivitas saat berada di rumah. Namun yang seharusnya pendapatan pelaku usaha menjadi naik alhasil jadi menurun, karena kecil kemungkinan bagi para pelanggan untuk datang langsung ke lokasi tersebut. Maka dari permasalahan diatas dibutuhkan Sistem Pendukung Keputusan yang dapat digunakan dalam pengambilan keputusan sehingga didapat rekomendasi untuk tanaman hias.

Sistem Pendukung Keputusan (SPK) merupakan sebuah sistem yang bertujuan dalam penyelesaian masalah, yang dilakukan secara sistematis terhadap suatu permasalahan melalui proses pengumpulan data menjadi informasi dengan didasari faktor-faktor pertimbangan dalam menentukan keputusan [4]. Dengan menggunakan metode yang dapat menyelesaikan permasalahan Multiple Atrribute Decision Making (MADM) yang sangat efektif memiliki kinerja terhadap data nilai dan kisaran nilai tertentu sesuai dengan yang telah ditentukan. [5]. Maka dari itu metode yang digunakan untuk membantu dalam penyelesaian masalah ini adalah Simple Additive Weighting (SAW) [6]. Metode SAW atau yang dikenal penjumlahan terbobot merupakan metode yang digunakan untuk mencari nilai bobot pada rating kinerja setiap alternatif pada semua atribut [7], [8]. Dalam perhitungannya membutuhkan proses normalisasi matriks keputusan ke suatu skala yang akan dibandingkan dengan semua kriteria dari setiap alternatif.

Penelitian sebelumnya menyatakan bahwa dalam menentukan pemilihan tanaman anggrek yang berkualitas unggul untuk memenuhi permintaan dari konsumen cukup sulit dilakukan [9]. Kriteria dalam pemilihan tanamannya yaitu umur tanaman, tinggi tanaman, kondisi daun, jumlah tangkai dan jumlah bunga. Karena itu diharapkan dengan adanya penelitian ini dapat membantu dalam proses seleksi kualitas tanaman hias dan mengetahui perangkingan dari hasil tes pada perhitungan sistemnya. Kelebihannya Berhasil dalam membuat sistem yang dapat membantu perusahaan juga konsumen dalam pengambilan keputusan untuk pemilihan dan dapat menampilkan hasil dari penilaian tanaman anggrek dari pihak konsumen. Kekurangannya fasilitas dalam tampilan sistem belum lengkap, jenis tanaman yang diuji hanya satu yaitu anggrek saja, belum ada hak akses yang membatasi antara pengelola perusahaan dan pengguna. Yang membedakan penelitian ini dengan penelitian ini yaitu dari segi alternatif, penelitian ini menggunakan 25 alternatif, 5 kriteria tanaman, selain itu penelitian ini juga digunakan untuk membantu dalam memudahkan proses pencatatan data. Penelitian lainnya juga menyatakan bahwa sulitnya menentukan pilihan tanaman hias yang cocok dijadikan tanaman hias bonsai [10]. Kriteria untuk tanaman bonsai yaitu bentuk, tanaman yang berumur panjang, batang, dahan yang mudah dibentuk, permukaan kulit yang menarik dan memiliki lekuk, berdaun kecil dan rimbun. Alternatif yang cocok untuk dijadikan tanaman bonsai ada tanaman Asoka Cina, Beringin, Asam, Cemara dan Melati. Maka karena itu untuk membantu petani bonsai dalam menentukan pilihan terhadap tanaman mana yang bisa dijadikan tanaman bonsai. Manfaat dari penelitian ini dapat memudahkan para petani dalam proses menentukan kelayakan tanaman hias bonsai. Kekurangannya penelitian ini hanya untuk tanaman hias bonsai saja. Penelitian lainnya lain juga menyatakan bahwa tidak mudah untuk menentukan pemilihan jenis bibit kelapa sawit dengan kualitasnya unggul untuk ditanam dilahan yang baru [11]. Selain itu adanya permintaan bibit kelapa sawit yang semakin banyak dengan mengakibatkan kesulitan yang dihadapi adalah dalam mengembangbiakkan kelapa sawit yang berasal dari biji. Dalam pemilihan ini perusahaan juga mengusahakan bibit dari Kultur jaringan yang didapat dari tenaga dari tenaga khusus dan Laboratorium. Akan tetapi masih saja kesulitan dalam menentukan pemilihan bibit kelapa sawit yang terbaik. Kriteria dalam pemilihan bibit yaitu harga, jenis bibit, dan cuaca juga mempengaruhi dalam proses pemilihan bibit.

Dengan adanya analisis penerapan metode SAW untuk pemilihan tanaman hias dapat mempermudah, mempercepat serta memberikan hasil rekomendasi yang akurat untuk keputusan pelanggan. Sehingga dapat membantu dalam proses pengambilan keputusan, menentukan rekomendasi yang sesuai dengan keinginan pelanggan. Sehingga nantinya dapat membantu para petani tanaman hias dan meningkatkan sektor pendapatan mereka. Batasan masalah dari penelitian ini hanya pada analisis penerapan metode Simple Additive Weighting (SAW) sebagai pendukung keputusan dalam menentukan pilihan tanaman hias terbaik. Dilihat dari alternatif pilihan dengan kriteria jenis tanaman hias Philodendron, Monstera, Aglonema, Caladium, dan Anggrek. Dengan kriteria yang sudah ditentukan yaitu jenis tanaman, harga tanaman, ukuran tanaman, umur tanaman, dan jarak. Untuk harga diperoleh pada Bulan Januari di Tahun 2021. Kemudian dalam perhitungan dan simulasinya menggunakan Microsoft Excel.

Kerangka pemikiran yang akan dilakukan pada yaitu: 1) Problem; permasalahan yang dihadapi yaitu belum menerapkan teknologi yang tekomputerisasi untuk membantu dalam proses promosi, rekomendasi. Kesulitan dalam menentukan pilihan tanaman mana yang Akan dibeli bisa dilihat dari kriteria yang ditawarkan untuk menjadi rekomendasi terbaik. Kemudian kurangnya informasi jarak tempuh yang jauh juga termasuk dalam pertimbangan menentukan keputusan untuk datang langsung ke lokasi dimana dimasa saat ini yang semua kegiatannya dibatasi atau harus dilakukan dari rumah. 2) Opportunities; peluang dilakukan analisis untuk pemilihan tanaman hias ini adalah karena banyaknya masyarakat yang berada di rumah tanpa berkegiatan membuat kebosanan menyebabkan kurangnya aktivitas. Maka dari itu menanam atau merawat tanaman hias menjadi bobby yang sedang trend dan banyak digemari oleh masyarakat saat ini. 3) Approach; pendekatan yang digunakan untuk menyelesaikan permasalahan pada pemilihan tanaman hias yaitu menggunakan metode Simple Additive Weighting (SAW). 4) Development; untuk membantu dalam perhitungan saat ini menggunakan Microsoft Office Excel. 5) Result; Harapan dari penelitian 
ini yaitu agar nantinya semua kegiatan yang masih manual bisa terintegrasi dengan sistem agar dapat memudahkan para pelaku usaha dan dapat membantu para pelanggan

\section{Metodologi}

Penelitian ini bersumber dari data-data primer yang merupakan suatu data yang dikumpulkan lalu diolah. Data penelitian bersumber dari catatan hasil observasi, dokumentasi, wawancara, maupun studi kepustakaan. Observasi dilakukan terhadap toko tanaman hias, dokumentasi diambil dari lokasi toko tanaman hias yang ditinjau secara langsung, serta wawancara pun dilakukan terhadap para pemilik toko tanaman hias agar mendapatkan informasi yang akurat sebagai acuan dalam penelitian. Penelitian ini termasuk ke dalam jenis metode penelitian survei. Survei ialah suatu proses penelitian yang digunakan untuk mengetahui permasalahan yang diambil dari data sampel yang didapatkan pada saat melakukan penelitian. Kemudian ditemukan hubungan antara suatu penilaian, variabel, dan masalah dalam proses pemasarannya. Oleh karena itu nantinya diharapkan hasil rekomendasi kepada si pengambil keputusan agar dapat bertindak secara lebih mudah dalam menyelesaikan masalahnya [12].

\section{Hasil dan Pembahasan}

Analisis penerapan metode SAW pada pemilihan tanaman hias sebagai bentuk untuk pengambilan keputusan pemilihan tanaman hias mana yang lebih unggul dilihat dari kriteria-kriteria yang telah ditentukan. Data sampel yang telah diambil diolah untuk menghasilkan perengkingan tanaman berdasarkan kriterianya sehingga didapatkan rekomendasi. Saat ini di wilayah Kabupaten Tanggamus belum ada suatu metode dalam menentukan keputusan terhadap pilihan tanaman hias yang diinginkan.

Teknik pengumpulan data yang dilakukan dalam penelitian ini menggunakan teknik observasi, wawancara, dokumentasi, dan studi kepustakaan. Observasi dilakukan di wilayah Kabupaten Tanggamus, Provinsi Lampung Indonesia. Observasi hanya melakukan pengamatan langsung ke 5 tempat penjualan tanaman hias dikarenakan tempat tersebut termasuk dalam tempat penjualan tanaman hias yang cukup terkenal di wilayah Kabupaten Tanggamus yaitu 1) Taman Bunga Chealsea; dan 2) Dahlia Nursey yang berada yang berada di Jl. Raya Gisting Atas Kecamatan Gisting, 3) Pusat Bunga Wonoharjo berada di Jl. Wonoharjo Kecamatan Sumberjo; 4) Linda Florist berada Jl. Sinar Petir, Talang Padang; dan 5) Rumah Anggrek Gulip berada di Jl. Banjar Negeri Kecamatan Gunung Alip. Wawancara dilakukan dengan mewawancarai para pemilik toko secara langsung pada bulan Januari Tahun 2021 guna untuk mendapatkan data yang akurat. yang digunakan dalam penentuan pemilihan tanaman hias sehingga dalam pengambilan keputusan sangat sulit. Data yang diambil dari penelitian ini berasal dari sekian banyak tempat penjualan tanaman hias yang ada di Kabupaten Tanggamus sehingga didapatkan data untuk perhitungan dengan menggunakan metode SAW. Alur langkah dalam menyelesaikan masalah dengan menggunakan metode SAW ini pada Gambar 1.

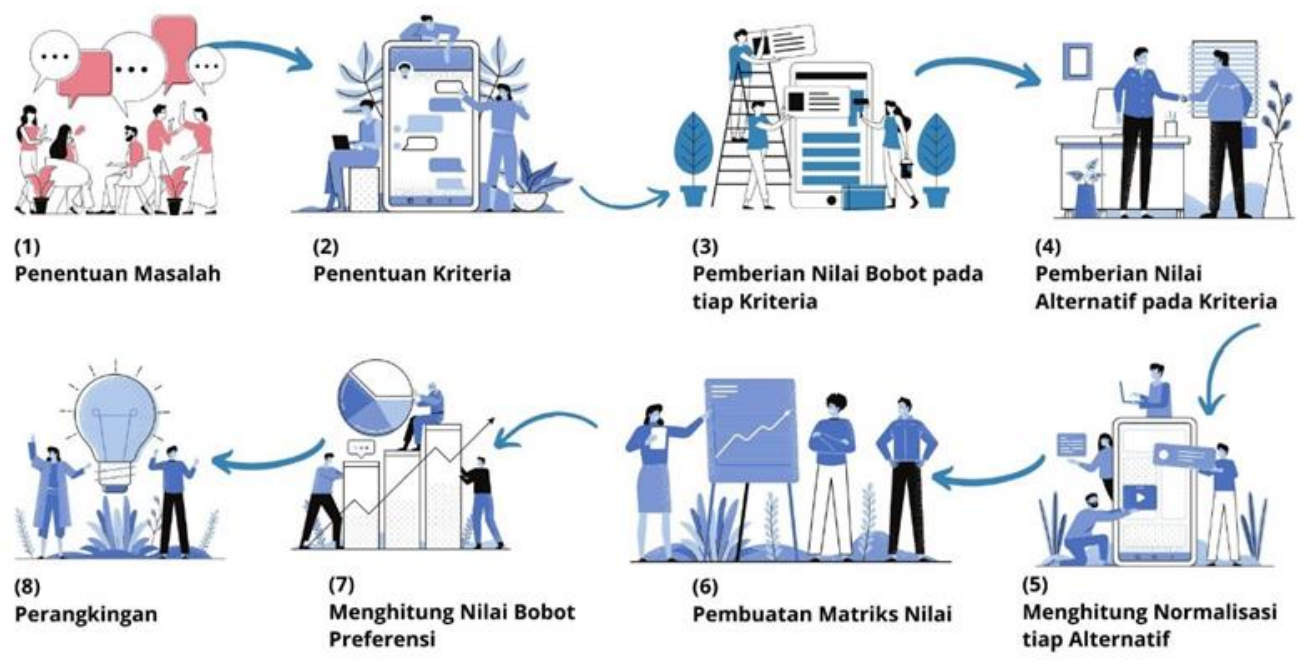

Gambar 1. Diagram Alur dalam penyelesaian Metode SAW

Untuk mendukung keputusan dalam pemilihan tananaman dibutuhkan kriteria-kriteria yang telah ditentukan dan juga alternatif dari semua jenis tanaman.
Maka dari itu semua data sampel yang telah diambil selanjutnya diolah dengan perhitungan metode SAW untuk menghasilkan prangkingan nilai tanaman 
berdasarkan kebutuhannya. Permasalahan terletak pada belum adanya sistem yang dapat membantu dalam pemilihan tanaman hias untuk menentukan keputusan dalam pemilihan saat membeli tanaman hias dan menjadi acuan dalam menentukan tanaman hias mana yang paling diminati para pelanggan saat ini yang bisa dilihat dari kriteria yang telah ditentukan sehingga menghasilkan rangking dan rekomendasi toko. Kemudian menjadi dasar dalam meningkat atau turunnya pendapatan pelaku usaha dilihat dari analisis yang telah diamati dalam proses pemilihan tanaman dan pemasaran tanaman hias.

Pada proses penentuan pemilihan tanaman hias dari sekian banyak pilihan mana yang paling banyak terjual. Dengan alternatif pilihan yaitu macam-macam tanaman hias, dimana ditentukan dari nilai pada setiap kriteria serta bobot kepentingan. Adapun output yang akan dihasilkan dari penelitian ini adalah sebuah alternatif yang memiliki nilai tertinggi dibandingkan dengan alternatif lain sehingga didaptakan rekomendasi toko yang dibutuhkan. Hasil output diambil dari rangking urutan alternatif tertinggi ke alternatif terendah. Alternatif yang dimaksud adalah tanaman hias.

Informasi yang dibutuhkan pada analisis dalam menentukan pemilihan tanaman hias mana yang diinginkan sesuai dengan proses penyelesaiannya yaitu: a. Menentukan kriteria yang akan digunakan Kriteria yang digunakan ada 5 yaitu 1) Jenis Tanaman, 2) Harga Tanaman, 3) Umur Tanaman, 4) Ukuran Tanaman, dan 5) Jarak Tempuh.

b. Memberikan bobot kepentingan pada setiap kriteria Dalam metode SAW terdapat kriteria yang dibutuhkan untuk menentukan tanaman hias mana yang akan menjadi pilihan sesuai dengan yang diinginkan oleh para pelanggan. Adapun kriteria yang sudah dikodekan dengan nilai bobot kepentingan yang sudah ditentukan adalah pada Tabel 1.

Tabel 1. Kriteria dan Nilai Bobot

\begin{tabular}{clrr}
\hline No. & Nama Kriteria & Kode & Bobot \\
1 & Jenis Tanaman & K1 & 0,3 \\
2 & Harga Tanaman & K2 & 0,25 \\
3 & Umur Tanaman & K3 & 0,2 \\
4 & Ukuran Tanaman & K4 & 0,15 \\
5 & Jarak Tempuh & K5 & 0,1 \\
\multicolumn{4}{c}{ Total Nilai Bobot } \\
\hline
\end{tabular}

Berikut adalah penjabaran dari masing-masing kriteria yang telah dikonversi ke bilangan fuz:y dengan nilai bobotnya yang sudah ditentukan: 1) Kriteria Jenis Tanaman (K1)
Kriteria jenis tanaman adalah jenis tanaman yang sedang banyak diminati di wilayah Kabupaten Tanggamus seperti pada Tabel 2.

Tabel 2. Kriteria dari Jenis Tanaman

\begin{tabular}{clc}
\hline No. & Jenis Tanaman & Nilai Bobot \\
& K1 & 5 \\
1 & Philodendron & 4 \\
2 & Monstera & 3 \\
3 & Aglonema & 2 \\
4 & Caladium & 1 \\
5 & Anggrek & \\
\hline
\end{tabular}

2) Kriteria Harga Tanaman (K2)

Kriteria harga tanaman adalah harga yang didapat dari hasil observasi pada bulan januari tahun 2021 di wilayah

Kabupaten Tanggamus dimana kisaran harga dibawah 50.000 sampai diatas 500.000 yaitu pada Tabel 3 .

Tabel 3. Kriteria dari Harga Tanaman

\begin{tabular}{llc}
\hline No & $\begin{array}{c}\text { Harga Tanaman } \\
\text { K2 }\end{array}$ & Nilai Bobot \\
1 & $<50.000$ & 5 \\
2 & $51.000-150.000$ & 4 \\
3 & $151.000-300.000$ & 3 \\
4 & $301.000-500.000$ & 2 \\
5 & $>500.000$ & 1 \\
\hline
\end{tabular}

3) Kriteria Umur Tanaman 
Kriteria umur tanaman adalah kisaran pertumbuhan tanaman dari data yang diperoleh pada observasi setiap toko di wilayah Kabupaten Tanggamus kisaran umur dibawah 2 bulan sampai diatas 8 bulan pada Tabel 4 .

Tabel 4. Kriteria dari Umur Tanaman

\begin{tabular}{clc}
\hline No & $\begin{array}{c}\text { Umur Tanaman } \\
\text { K3 }\end{array}$ & Nilai Bobot \\
\hline 1 & $<2$ Bulan & 5 \\
2 & $2-4$ Bulan & 4 \\
3 & $4-6$ bulan & 3 \\
4 & $6-8$ Bulan & 2 \\
5 & $>8$ bulan & 1 \\
\hline
\end{tabular}

4) Kriteria Ukuran Tanaman

Kriteria ukuran tanaman adalah diameter atau tinggi dari di wilayah Kabupaten Tanggamus kisaran diatas $20 \mathrm{~cm}$ suatu tanaman yang diperoleh pada observasi setiap toko sampai diatas $81 \mathrm{~cm}$ yaitu pada Tabel 5 .

Tabel 5. Kriteria dari Ukuran Tanaman

\begin{tabular}{clc}
\hline No & $\begin{array}{c}\text { Ukuran Tanaman } \\
\text { K4 }\end{array}$ & Nilai Bobot \\
\hline 1 & $<20 \mathrm{~cm}$ & 5 \\
2 & $21 \mathrm{~cm}-40 \mathrm{~cm}$ & 4 \\
3 & $41 \mathrm{~cm}-60 \mathrm{~cm}$ & 3 \\
4 & $61 \mathrm{~cm}-80 \mathrm{~cm}$ & 2 \\
5 & $>81 \mathrm{~cm}$ & 1 \\
\hline
\end{tabular}

5) Kriteria Jarak Tempuh

Kriteria jarak tempuh adalah angka yang menunjukan Kabupaten Tanggamus kisaran $<5 \mathrm{~km}$ sampai $>30 \mathrm{~km}$ seberapa jauh lokasi tanaman hias yang diperjualkan, yaitu sebagai berikut: diperoleh dari hasil observasi setiap toko di wilayah

\begin{tabular}{ccr}
\multicolumn{3}{c}{ Tabel 6. Kriteria dari Jarak Tempuh } \\
\hline No & Jarak Tempuh & Nilai Bobot \\
& K5 \\
\hline 1 & $<5 \mathrm{~km}$ & 5 \\
2 & $5 \mathrm{~km}-15 \mathrm{~km}$ & 4 \\
3 & $15 \mathrm{~km}-20 \mathrm{~km}$ & 3 \\
4 & $20 \mathrm{~km}-30 \mathrm{~km}$ & 2 \\
5 & $>30 \mathrm{~km}$ & 1 \\
\hline
\end{tabular}

c. Memberikan nilai tanaman hias pada setiap kriteria

Membuat tabel real untuk menentukan nilai bobot dari tanaman hias dan 5 kriteria dari setiap tanaman dimana setiap atlernatif tanaman hias yang diambil sebagai diperoleh dari hasil observasi dari beberapa toko di sampel. Dalam penelitian ini digunakan 25 macam sampel wilayah Kabupaten Tanggamus yaitu pada Tabel 7.

Tabel 7. Data Sampel Alternatif dan Kriteria

\begin{tabular}{|c|c|c|c|c|c|c|c|c|c|c|}
\hline \multirow{2}{*}{$\begin{array}{l}\text { No. } \\
1\end{array}$} & Alternatif & \multirow{2}{*}{$\begin{array}{c}\text { Jenis } \\
\text { Tanaman } \\
\text { Philodendron }\end{array}$} & \multicolumn{2}{|c|}{$\begin{array}{c}\text { Harga } \\
\text { Tanaman }\end{array}$} & \multicolumn{2}{|c|}{$\begin{array}{c}\text { Umur } \\
\text { Tanaman }\end{array}$} & \multicolumn{2}{|c|}{$\begin{array}{c}\text { Ukuran } \\
\text { Tanaman }\end{array}$} & \multicolumn{2}{|c|}{$\begin{array}{c}\text { Jarak } \\
\text { Tempuh }\end{array}$} \\
\hline & Philodendron Imperal Red Cardinal & & Rp. & 150000 & 5 & Bulan & 50 & $\mathrm{~cm}$ & 35 & $\mathrm{~km}$ \\
\hline 2 & Philodendron Prince Orange & Philodendron & Rp. & 500000 & 8 & Bulan & 15 & $\mathrm{~cm}$ & 6 & $\mathrm{~km}$ \\
\hline 3 & Philodendron Lemon Lime & Philodendron & Rp. & 35000 & 7 & Bulan & 21 & $\mathrm{~cm}$ & 5 & $\mathrm{~km}$ \\
\hline 4 & Philodendron Milano & Philodendron & Rp. & 250000 & 3 & Bulan & 20 & $\mathrm{~cm}$ & 13 & $\mathrm{~km}$ \\
\hline 5 & Philodendron Congo Rojo & Philodendron & Rp. & 650000 & 5 & Bulan & 18 & $\mathrm{~cm}$ & 10 & $\mathrm{~km}$ \\
\hline 6 & Monstera Deleciosa & Monstera & Rp. & 175000 & 6 & Bulan & 45 & $\mathrm{~cm}$ & 15 & $\mathrm{~km}$ \\
\hline 7 & Monstera Adausonil & Monstera & Rp. & 500000 & 12 & Bulan & 95 & $\mathrm{~cm}$ & 22 & $\mathrm{~km}$ \\
\hline 8 & Monstera Borsigiana & Monstera & Rp. & 250000 & 4 & Bulan & 55 & $\mathrm{~cm}$ & 5 & $\mathrm{~km}$ \\
\hline 9 & Monstera Dubia & Monstera & Rp. & 350000 & 8 & Bulan & 60 & $\mathrm{~cm}$ & 15 & $\mathrm{~km}$ \\
\hline
\end{tabular}




\begin{tabular}{|c|c|c|c|c|c|c|c|c|c|c|}
\hline \multirow{2}{*}{$\begin{array}{l}\text { No. } \\
10\end{array}$} & \multirow{2}{*}{$\begin{aligned} \text { Alternatif } \\
\text { Monstera Variegata }\end{aligned}$} & \multirow{2}{*}{$\begin{array}{c}\text { Jenis } \\
\text { Tanaman } \\
\text { Monstera }\end{array}$} & \multicolumn{2}{|c|}{$\begin{array}{c}\text { Harga } \\
\text { Tanaman }\end{array}$} & \multicolumn{2}{|c|}{$\begin{array}{c}\text { Umur } \\
\text { Tanaman }\end{array}$} & \multicolumn{2}{|c|}{$\begin{array}{c}\text { Ukuran } \\
\text { Tanaman }\end{array}$} & \multicolumn{2}{|c|}{$\begin{array}{c}\text { Jarak } \\
\text { Tempuh }\end{array}$} \\
\hline & & & Rp. & 200000 & 7 & Bulan & 40 & $\mathrm{~cm}$ & 30 & $\mathrm{~km}$ \\
\hline 11 & Aglonema Claudia & Aglonema & Rp. & 95000 & 2 & Bulan & 25 & $\mathrm{~cm}$ & 7 & $\mathrm{~km}$ \\
\hline 12 & Aglonema Red Ruby & Aglonema & Rp. & 125000 & 4 & Bulan & 55 & $\mathrm{~cm}$ & 21 & $\mathrm{~km}$ \\
\hline 13 & Aglonema Lipstik & Aglonema & Rp. & 25000 & 2 & Bulan & 20 & $\mathrm{~cm}$ & 5 & $\mathrm{~km}$ \\
\hline 14 & Aglonema Red Sumatra & Aglonema & Rp. & 350000 & 5 & Bulan & 65 & $\mathrm{~cm}$ & 32 & $\mathrm{~km}$ \\
\hline 15 & Aglonema Pictum Tricolor & Aglonema & Rp. & 195000 & 3 & Bulan & 20 & $\mathrm{~cm}$ & 43 & $\mathrm{~km}$ \\
\hline 16 & Caladium Tikus & Caladium & Rp. & 45000 & 2 & Bulan & 25 & $\mathrm{~cm}$ & 1 & $\mathrm{~km}$ \\
\hline 17 & Caladium Tengkoral & Caladium & Rp. & 180000 & 5 & Bulan & 50 & $\mathrm{~cm}$ & 17 & $\mathrm{~km}$ \\
\hline 18 & Caladium Wayang & Caladium & Rp. & 100000 & 3 & Bulan & 35 & $\mathrm{~cm}$ & 26 & $\mathrm{~km}$ \\
\hline 19 & Caladium Baret Merah & Caladium & Rp. & 85000 & 2 & Bulan & 40 & $\mathrm{~cm}$ & 5 & $\mathrm{~km}$ \\
\hline 20 & Caladium Kuping Kelinci & Caladium & Rp. & 20000 & 2 & Bulan & 25 & $\mathrm{~cm}$ & 3 & $\mathrm{~km}$ \\
\hline 21 & Anggrek Kuku Macan & Anggrek & Rp. & 200000 & 8 & Bulan & 87 & $\mathrm{~cm}$ & 23 & $\mathrm{~km}$ \\
\hline 22 & Anggrek Ekor Tupai & Anggrek & Rp. & 15000 & 1 & Bulan & 20 & $\mathrm{~cm}$ & 5 & $\mathrm{~km}$ \\
\hline 23 & Anggrek Bulan & Anggrek & Rp. & 45000 & 2 & Bulan & 18 & $\mathrm{~cm}$ & 6 & $\mathrm{~km}$ \\
\hline 24 & Anggrek Tanah & Anggrek & Rp. & 55000 & 3 & Bulan & 32 & $\mathrm{~cm}$ & 2 & $\mathrm{~km}$ \\
\hline 25 & Anggrek Tebu & Anggrek & Rp. & 100000 & 5 & Bulan & 80 & $\mathrm{~cm}$ & 33 & $\mathrm{~km}$ \\
\hline
\end{tabular}

Setelah ditentukan sampel tabel di atas kemudian nilai kriteria. Berikut adalah Tabel 8 tabel nilai dari setiap menentukan bobot pada setiap kriteria yang digunakan. alternatif.

Nilai bobot ini diperoleh dari hasil kecocokan pada setiap

Tabel 8. Nilai data dari Setiap Alternatif Kriteria

\begin{tabular}{cccccc}
\hline Alternatif & & \multicolumn{3}{c}{ Kriteria } \\
& Benefit & Cost & Benefit & Benefit & Cost \\
& K1 & K2 & K3 & K4 & K5 \\
\hline A1 & 5 & 4 & 3 & 3 & 1 \\
A2 & 5 & 2 & 1 & 5 & 4 \\
A3 & 5 & 5 & 2 & 4 & 5 \\
A4 & 5 & 3 & 4 & 5 & 4 \\
A5 & 5 & 1 & 3 & 5 & 4 \\
A6 & 4 & 3 & 2 & 3 & 4 \\
A7 & 4 & 2 & 1 & 1 & 2 \\
A8 & 4 & 3 & 3 & 3 & 5 \\
A9 & 4 & 2 & 1 & 3 & 4 \\
A10 & 4 & 3 & 2 & 4 & 2 \\
A11 & 3 & 4 & 4 & 4 & 4 \\
A12 & 3 & 4 & 3 & 3 & 2 \\
A13 & 3 & 5 & 4 & 5 & 5 \\
A14 & 3 & 2 & 3 & 2 & 1 \\
A15 & 3 & 3 & 4 & 5 & 1 \\
A16 & 2 & 5 & 4 & 4 & 5 \\
A17 & 2 & 3 & 3 & 3 & 3 \\
A18 & 2 & 4 & 4 & 4 & 2 \\
A19 & 2 & 4 & 4 & 4 & 5 \\
A20 & 2 & 5 & 4 & 4 & 5 \\
A21 & 1 & 3 & 1 & 1 & 2 \\
A22 & 1 & 5 & 5 & 5 & 5 \\
A23 & 1 & 5 & 4 & 5 & 4 \\
A24 & 1 & 4 & 4 & 4 & 5 \\
A25 & 1 & 4 & 3 & 2 & 1 \\
Nilai Max & 5 & 5 & 5 & 5 & 5 \\
Nilai Min & 1 & 1 & 1 & 1 & 1 \\
\hline & & & & & \\
\hline
\end{tabular}

d. Normalisasi pada setiap alternatif

Normalisasi pada setiap alternatif adalah perhitungan kriteia yang digunakan termasuk atribut keuntungan. untuk menentukan nilai dari Normalisasi setiap alternatif.

Dimana K1, K3 dan K4 termasuk katagori benenfit karena Maka digunakan rumus sebagai berikut: 
$r i j=\frac{X i j}{M a x X i j}$

r1.1 sampai dengan $r 25.1$ adalah nilai normalisasi dimana untuk pencahariannya $\mathrm{X}_{\mathrm{ij}}$ adalah nilai dari setiap kriteria pada baris pertama kolom pertama dibagi dengan nilai
Max dari setiap kriteria yang digunakan. Dari kolom K1 nilai maximalnya adalah ' 5 ', maka setiap baris kolom $\mathrm{K} 1$ dibagi oleh nilai maximal $\mathrm{K} 1$.

$$
\begin{aligned}
& r 1.1=\frac{5}{\operatorname{Max}\{5,5,5,5,5,4,4,4,4,4,3,3,3,3,3,2,2,2,2,2,1,1,1,1,1\}}=\frac{5}{5}=1 \\
& r 2.1=\frac{5}{\operatorname{Max}\{5,5,5,5,5,4,4,4,4,4,3,3,3,3,3,2,2,2,2,2,1,1,1,1,1\}}=\frac{5}{5}=1 \\
& r 3.1=\frac{5}{\operatorname{Max}\{5,5,5,5,5,4,4,4,4,4,3,3,3,3,3,2,2,2,2,2,1,1,1,1,1\}}=\frac{5}{5}=1 \\
& r 4.1=\frac{5}{\operatorname{Max}\{5,5,5,5,5,4,4,4,4,4,3,3,3,3,3,2,2,2,2,2,1,1,1,1,1\}}=\frac{5}{5}=1 \\
& r 5.1=\frac{5}{\operatorname{Max}\{5,5,5,5,5,4,4,4,4,4,3,3,3,3,3,2,2,2,2,2,1,1,1,1,1\}}=\frac{5}{5}=1 \\
& r 6.1=\frac{4}{\operatorname{Max}\{5,5,5,5,5,4,4,4,4,4,3,3,3,3,3,2,2,2,2,2,1,1,1,1,1\}}=\frac{4}{5}=0,8 \\
& r 7.1=\frac{4}{\operatorname{Max}\{5,5,5,5,5,4,4,4,4,4,3,3,3,3,3,2,2,2,2,2,1,1,1,1,1\}}=\frac{4}{5}=0,8 \\
& r 8.1=\frac{4}{\operatorname{Max}\{5,5,5,5,5,4,4,4,4,4,3,3,3,3,3,2,2,2,2,2,1,1,1,1,1\}}=\frac{4}{5}=0,8 \\
& r 9.1=\frac{4}{\operatorname{Max}\{5,5,5,5,5,4,4,4,4,4,3,3,3,3,3,2,2,2,2,2,1,1,1,1,1\}}=\frac{4}{5}=0,8 \\
& r 10.1=\frac{4}{\operatorname{Max}\{5,5,5,5,5,4,4,4,4,4,3,3,3,3,3,2,2,2,2,2,1,1,1,1,1\}}=\frac{4}{5}=0,8 \\
& r 11.1=\frac{3}{\operatorname{Max}\{5,5,5,5,5,4,4,4,4,4,3,3,3,3,3,2,2,2,2,2,1,1,1,1,1\}}=\frac{3}{5}=0,6 \\
& r 12.1=\frac{3}{\operatorname{Max}\{5,5,5,5,5,4,4,4,4,4,3,3,3,3,3,2,2,2,2,2,1,1,1,1,1\}}=\frac{3}{5}=0,6 \\
& r 13.1=\frac{3}{\operatorname{Max}\{5,5,5,5,5,4,4,4,4,4,3,3,3,3,3,2,2,2,2,2,1,1,1,1,1\}}=\frac{3}{5}=0,6 \\
& r 14.1=\frac{3}{\operatorname{Max}\{5,5,5,5,5,4,4,4,4,4,3,3,3,3,3,2,2,2,2,2,1,1,1,1,1\}}=\frac{3}{5}=0,6 \\
& r 15.1=\frac{3}{\operatorname{Max}\{5,5,5,5,5,4,4,4,4,4,3,3,3,3,3,2,2,2,2,2,1,1,1,1,1\}}=\frac{3}{5}=0,6 \\
& r 16.1=\frac{2}{\operatorname{Max}\{5,5,5,5,5,4,4,4,4,4,3,3,3,3,3,2,2,2,2,2,1,1,1,1,1\}}=\frac{2}{5}=0,4 \\
& r 17.1=\frac{2}{\operatorname{Max}\{5,5,5,5,5,4,4,4,4,4,3,3,3,3,3,2,2,2,2,2,1,1,1,1,1\}}=\frac{2}{5}=0,4 \\
& r 18.1=\frac{2}{\operatorname{Max}\{5,5,5,5,5,4,4,4,4,4,3,3,3,3,3,2,2,2,2,2,1,1,1,1,1\}}=\frac{2}{5}=0,4 \\
& r 19.1=\frac{2}{\operatorname{Max}\{5,5,5,5,5,4,4,4,4,4,3,3,3,3,3,2,2,2,2,2,1,1,1,1,1\}}=\frac{2}{5}=0,4 \\
& r 20.1=\frac{2}{\operatorname{Max}\{5,5,5,5,5,4,4,4,4,4,3,3,3,3,3,2,2,2,2,2,1,1,1,1,1\}}=\frac{2}{5}=0,4 \\
& r 21.1=\frac{1}{\operatorname{Max}\{5,5,5,5,5,4,4,4,4,4,3,3,3,3,3,2,2,2,2,2,1,1,1,1,1\}}=\frac{1}{5}=0,2
\end{aligned}
$$




$$
\begin{aligned}
& r 22.1=\frac{1}{\operatorname{Max}\{5,5,5,5,5,4,4,4,4,4,3,3,3,3,3,2,2,2,2,2,1,1,1,1,1\}}=\frac{1}{5}=0,2 \\
& r 23.1=\frac{1}{\operatorname{Max}\{5,5,5,5,5,4,4,4,4,4,3,3,3,3,3,2,2,2,2,2,1,1,1,1,1\}}=\frac{1}{5}=0,2 \\
& r 24.1=\frac{1}{\operatorname{Max}\{5,5,5,5,5,4,4,4,4,4,3,3,3,3,3,2,2,2,2,2,1,1,1,1,1\}}=\frac{1}{5}=0,2 \\
& r 25.1=\frac{1}{\operatorname{Max}\{5,5,5,5,5,4,4,4,4,4,3,3,3,3,3,2,2,2,2,2,1,1,1,1,1\}}=\frac{1}{5}=0,2
\end{aligned}
$$

r1.3 sampai dengan r25.3 adalah nilai normalisasi dimana dari setiap kriteria yang digunakan. Dari kolom K3 nilai untuk pencahariannya $\mathrm{X}_{\mathrm{ij}}$ adalah nilai dari setiap kriteria maximalnya adalah '5', maka setiap baris kolom $\mathrm{K} 3$ dibagi pada baris pertama kolom ketiga dibagi dengan nilai Max oleh nilai maximal $\mathrm{K} 3$.

$$
\begin{aligned}
& r 1.3=\frac{3}{\operatorname{Max}\{3,1,2,4,3,2,1,3,1,2,4,3,4,3,4,4,3,4,4,4,1,5,4,4,3\}}=\frac{3}{5}=0,6 \\
& r 2.3=\frac{1}{\operatorname{Max}\{3,1,2,4,3,2,1,3,1,2,4,3,4,3,4,4,3,4,4,4,1,5,4,4,3\}}=\frac{1}{5}=0,2 \\
& r 3.3=\frac{2}{\operatorname{Max}\{3,1,2,4,3,2,1,3,1,2,4,3,4,3,4,4,3,4,4,4,1,5,4,4,3\}}=\frac{2}{5}=0,4 \\
& r 4.3=\frac{4}{\operatorname{Max}\{3,1,2,4,3,2,1,3,1,2,4,3,4,3,4,4,3,4,4,4,1,5,4,4,3\}}=\frac{4}{5}=0,8 \\
& r 5.3=\frac{3}{\operatorname{Max}\{3,1,2,4,3,2,1,3,1,2,4,3,4,3,4,4,3,4,4,4,1,5,4,4,3\}}=\frac{3}{5}=0,6 \\
& r 6.3=\frac{2}{\operatorname{Max}\{3,1,2,4,3,2,1,3,1,2,4,3,4,3,4,4,3,4,4,4,1,5,4,4,3\}}=\frac{2}{5}=0,4 \\
& r 7.3=\frac{1}{\operatorname{Max}\{3,1,2,4,3,2,1,3,1,2,4,3,4,3,4,4,3,4,4,4,1,5,4,4,3\}}=\frac{1}{5}=0,2 \\
& r 18.3=\frac{3}{\operatorname{Max}\{3,1,2,4,3,2,1,3,1,2,4,3,4,3,4,4,3,4,4,4,1,5,4,4,3\}}=\frac{3}{5}=0,6 \\
& r 16.3=\frac{1}{\operatorname{Max}\{3,1,2,4,3,2,1,3,1,2,4,3,4,3,4,4,3,4,4,4,1,5,4,4,3\}}=\frac{4}{5}=0,8 \\
& r 13.3=\frac{3}{\operatorname{Max}\{3,1,2,4,3,2,1,3,1,2,4,3,4,3,4,4,3,4,4,4,1,5,4,4,3\}}=\frac{4}{5}=0,8 \\
& r 11.3=\frac{3}{\operatorname{Max}\{3,1,2,4,3,2,1,3,1,2,4,3,4,3,4,4,4,2,1,3,1,1,2,4,3,4,3,4,4,4,3,4,4,4,4,1,5,4,4,3\}}=\frac{1}{5}=0,2 \\
& r 10.3=\frac{2}{\operatorname{Max}\{3,1,2,4,3,2,1,3,1,2,4,3,4,3,4,4,3,3,4,4,4,1,5,4,4,3\}}=\frac{3}{5}=0,4 \\
& r 15.3=\frac{4}{\operatorname{Max}\{3,1,2,4,3,2,1,3,1,2,4,3,4,3,4,4,3,4,4,4,1,5,4,4,3\}}=\frac{3}{5}=0,6
\end{aligned}
$$




$$
\begin{aligned}
& r 19.3=\frac{4}{\operatorname{Max}\{3,1,2,4,3,2,1,3,1,2,4,3,4,3,4,4,3,4,4,4,1,5,4,4,3\}}=\frac{4}{5}=0,8 \\
& r 20.3=\frac{4}{\operatorname{Max}\{3,1,2,4,3,2,1,3,1,2,4,3,4,3,4,4,3,4,4,4,1,5,4,4,3\}}=\frac{4}{5}=0,8 \\
& r 21.3=\frac{1}{\operatorname{Max}\{3,1,2,4,3,2,1,3,1,2,4,3,4,3,4,4,3,4,4,4,1,5,4,4,3\}}=\frac{1}{5}=0,2 \\
& r 22.3=\frac{5}{\operatorname{Max}\{3,1,2,4,3,2,1,3,1,2,4,3,4,3,4,4,3,4,4,4,1,5,4,4,3\}}=\frac{5}{5}=1 \\
& r 23.3=\frac{4}{\operatorname{Max}\{3,1,2,4,3,2,1,3,1,2,4,3,4,3,4,4,3,4,4,4,1,5,4,4,3\}}=\frac{4}{5}=0,8 \\
& r 24.3=\frac{4}{\operatorname{Max}\{3,1,2,4,3,2,1,3,1,2,4,3,4,3,4,4,3,4,4,4,1,5,4,4,3\}}=\frac{4}{5}=0,8 \\
& r 25.3=\frac{3}{\operatorname{Max}\{3,1,2,4,3,2,1,3,1,2,4,3,4,3,4,4,3,4,4,4,1,5,4,4,3\}}=\frac{3}{5}=0,6
\end{aligned}
$$

r1.4 sampai dengan r25.4 adalah nilai normalisasi dimana Max dari setiap kriteria yang digunakan. Dari kolom K4 untuk pencahariannya $\mathrm{X}_{\mathrm{ij}}$ adalah nilai dari setiap kriteria nilai maximal adalah '5', maka setiap baris kolom $\mathrm{K} 4$ pada baris pertama kolom ke empat dibagi dengan nilai dibagi oleh nilai maximal K4.

$$
\begin{aligned}
& \mathrm{r} 1.4=\frac{3}{\operatorname{Max}\{3,5,4,5,5,3,1,3,3,4,4,3,5,2,5,4,3,4,4,4,1,5,5,4,2\}}=\frac{3}{5}=0,6 \\
& \mathrm{r} 2.4=\frac{5}{\operatorname{Max}\{3,5,4,5,5,3,1,3,3,4,4,3,5,2,5,4,3,4,4,4,1,5,5,4,2\}}=\frac{5}{5}=0,8 \\
& \mathrm{r} 3.4=\frac{4}{\operatorname{Max}\{3,5,4,5,5,3,1,3,3,4,4,3,5,2,5,4,3,4,4,4,1,5,5,4,2\}}=\frac{4}{5}=0,4 \\
& \mathrm{r} 4.4=\frac{5}{\operatorname{Max}\{3,5,4,5,5,3,1,3,3,4,4,3,5,2,5,4,3,4,4,4,1,5,5,4,2\}}=\frac{5}{5}=1 \\
& \mathrm{r} 5.4=\frac{5}{\operatorname{Max}\{3,5,4,5,5,3,1,3,3,4,4,3,5,2,5,4,3,4,4,4,1,5,5,4,2\}}=\frac{5}{5}=1 \\
& \mathrm{r} 6.4=\frac{3}{\operatorname{Max}\{3,5,4,5,5,3,1,3,3,4,4,3,5,2,5,4,3,4,4,4,1,5,5,4,2\}}=\frac{3}{5}=0,4 \\
& \mathrm{r} 7.4=\frac{1}{\operatorname{Max}\{3,5,4,5,5,3,1,3,3,4,4,3,5,2,5,4,3,4,4,4,1,5,5,4,2\}}=\frac{1}{5}=0,2 \\
& \mathrm{r} 8.4=\frac{3}{\operatorname{Max}\{3,5,4,5,5,3,1,3,3,4,4,3,5,2,5,4,3,4,4,4,1,5,5,4,2\}}=\frac{3}{5}=0,6 \\
& \mathrm{r} 9.4=\frac{3}{\operatorname{Max}\{3,5,4,5,5,3,1,3,3,4,4,3,5,2,5,4,3,4,4,4,1,5,5,4,2\}}=\frac{3}{5}=0,6 \\
& \mathrm{r} 10.4=\frac{4}{\operatorname{Max}\{3,5,4,5,5,3,1,3,3,4,4,3,5,2,5,4,3,4,4,4,1,5,5,4,2\}}=\frac{4}{5}=0,8 \\
& \mathrm{r} 11.4=\frac{4}{\operatorname{Max}\{3,5,4,5,5,3,1,3,3,4,4,3,5,2,5,4,3,4,4,4,1,5,5,4,2\}}=\frac{4}{5}=0,8 \\
& \mathrm{r} 12.4=\frac{3}{\operatorname{Max}\{3,5,4,5,5,3,1,3,3,4,4,3,5,2,5,4,3,4,4,4,1,5,5,4,2\}}=\frac{3}{5}=0,6 \\
& \mathrm{r} 13.4=\frac{5}{\operatorname{Max}\{3,5,4,5,5,3,1,3,3,4,4,3,5,2,5,4,3,4,4,4,1,5,5,4,2\}}=\frac{5}{5}=1 \\
& \mathrm{r} 14.4=\frac{2}{\operatorname{Max}\{3,5,4,5,5,3,1,3,3,4,4,3,5,2,5,4,3,4,4,4,1,5,5,4,2\}}=\frac{2}{5}=0,4 \\
& \mathrm{r} 15.4=\frac{5}{\operatorname{Max}\{3,5,4,5,5,3,1,3,3,4,4,3,5,2,5,4,3,4,4,4,1,5,5,4,2\}}=\frac{5}{5}=1
\end{aligned}
$$




$$
\begin{aligned}
& \mathrm{r} 16.4=\frac{4}{\operatorname{Max}\{3,5,4,5,5,3,1,3,3,4,4,3,5,2,5,4,3,4,4,4,1,5,5,4,2\}}=\frac{4}{5}=0,8 \\
& \mathrm{r} 17.4=\frac{3}{\operatorname{Max}\{3,5,4,5,5,3,1,3,3,4,4,3,5,2,5,4,3,4,4,4,1,5,5,4,2\}}=\frac{3}{5}=0,6 \\
& \mathrm{r} 18.4=\frac{4}{\operatorname{Max}\{3,5,4,5,5,3,1,3,3,4,4,3,5,2,5,4,3,4,4,4,1,5,5,4,2\}}=\frac{4}{5}=0,8 \\
& \mathrm{r} 19.4=\frac{4}{\operatorname{Max}\{3,5,4,5,5,3,1,3,3,4,4,3,5,2,5,4,3,4,4,4,1,5,5,4,2\}}=\frac{4}{5}=0,8 \\
& \mathrm{r} 20.4=\frac{4}{\operatorname{Max}\{3,5,4,5,5,3,1,3,3,4,4,3,5,2,5,4,3,4,4,4,1,5,5,4,2\}}=\frac{4}{5}=0,8 \\
& \mathrm{r} 21.4=\frac{1}{\operatorname{Max}\{3,5,4,5,5,3,1,3,3,4,4,3,5,2,5,4,3,4,4,4,1,5,5,4,2\}}=\frac{1}{5}=0,2 \\
& \mathrm{r} 22.4=\frac{5}{\operatorname{Max}\{3,5,4,5,5,3,1,3,3,4,4,3,5,2,5,4,3,4,4,4,1,5,5,4,2\}}=\frac{5}{5}=1 \\
& \mathrm{r} 23.4=\frac{5}{\operatorname{Max}\{3,5,4,5,5,3,1,3,3,4,4,3,5,2,5,4,3,4,4,4,1,5,5,4,2\}}=\frac{5}{5}=1 \\
& \mathrm{r} 24.4=\frac{4}{\operatorname{Max}\{3,5,4,5,5,3,1,3,3,4,4,3,5,2,5,4,3,4,4,4,1,5,5,4,2\}}=\frac{4}{5}=0,8 \\
& \mathrm{r} 25.4=\frac{2}{\operatorname{Max}\{3,5,4,5,5,3,1,3,3,4,4,3,5,2,5,4,3,4,4,4,1,5,5,4,2\}}=\frac{2}{5}=0,4
\end{aligned}
$$

Selanjutnya dilakukan perhitungan untuk menentukan nilai dari normalisasi alternatif katagori cost yaitu K2, dan K5 dengan rumus sebagai berikut:

$r i j=\frac{M i n X i j}{X i j}$

r1.2 sampai dengan $r 25.2$ adalah nilai normalisasi dimana untuk pencahariannya $\operatorname{MinX}_{\mathrm{ij}}$ adalah nilai minimal dari setiap kriteria dibagi dengan $\mathrm{Xij}$ adalah nilai kriteria pada baris pertama kolom ke dua yang digunakan. Dari kolom K2 nilai minimalnya adalah ' 1 '. Maka setiap baris dari kolom K2 menjadi penyebut dari nilai kolom K2.

$$
\begin{aligned}
& \mathrm{r} 1.2=\frac{\operatorname{Min}\{4,2,5,3,1,3,2,3,2,3,4,4,5,2,3,5,3,4,4,5,3,5,5,4,4\}}{4}=\frac{1}{4}=0,25 \\
& \mathrm{r} 2.2=\frac{\operatorname{Min}\{4,2,5,3,1,3,2,3,2,3,4,4,5,2,3,5,3,4,4,5,3,5,5,4,4\}}{2}=\frac{1}{2}=0,5 \\
& \mathrm{r} 3.2=\frac{\operatorname{Min}\{4,2,5,3,1,3,2,3,2,3,4,4,5,2,3,5,3,4,4,5,3,5,5,4,4\}}{5}=\frac{1}{5}=0,2 \\
& \mathrm{r} 4.2=\frac{\operatorname{Min}\{4,2,5,3,1,3,2,3,2,3,4,4,5,2,3,5,3,4,4,5,3,5,5,4,4\}}{3}=\frac{1}{3}=0,33 \\
& \mathrm{r} 5.2=\frac{\operatorname{Min}\{4,2,5,3,1,3,2,3,2,3,4,4,5,2,3,5,3,4,4,5,3,5,5,4,4\}}{1}=\frac{1}{1}=1 \\
& \mathrm{r} 6.2=\frac{\operatorname{Min}\{4,2,5,3,1,3,2,3,2,3,4,4,5,2,3,5,3,4,4,5,3,5,5,4,4\}}{3}=\frac{1}{3}=0,33 \\
& \mathrm{r} 7.2=\frac{\operatorname{Min}\{4,2,5,3,1,3,2,3,2,3,4,4,5,2,3,5,3,4,4,5,3,5,5,4,4\}}{2}=\frac{1}{2}=0,5 \\
& \mathrm{r} 8.2=\frac{\operatorname{Min}\{4,2,5,3,1,3,2,3,2,3,4,4,5,2,3,5,3,4,4,5,3,5,5,4,4\}}{3}=\frac{1}{3}=0,33 \\
& \mathrm{r} 9.2=\frac{\operatorname{Min}\{4,2,5,3,1,3,2,3,2,3,4,4,5,2,3,5,3,4,4,5,3,5,5,4,4\}}{2}=\frac{1}{2}=0,5 \\
& \mathrm{r} 10.2=\frac{\operatorname{Min}\{4,2,5,3,1,3,2,3,2,3,4,4,5,2,3,5,3,4,4,5,3,5,5,4,4\}}{3}=\frac{1}{3}=0,33
\end{aligned}
$$




$$
\begin{aligned}
& \mathrm{r} 11.2=\frac{\operatorname{Min}\{4,2,5,3,1,3,2,3,2,3,4,4,5,2,3,5,3,4,4,5,3,5,5,4,4\}}{4}=\frac{1}{4}=0,25 \\
& \mathrm{r} 12.2=\frac{\operatorname{Min}\{4,2,5,3,1,3,2,3,2,3,4,4,5,2,3,5,3,4,4,5,3,5,5,4,4\}}{4}=\frac{1}{4}=0,25 \\
& \mathrm{r} 13.1=\frac{\operatorname{Min}\{4,2,5,3,1,3,2,3,2,3,4,4,5,2,3,5,3,4,4,5,3,5,5,4,4\}}{5}=\frac{1}{5}=0,2 \\
& \mathrm{r} 14.1=\frac{\operatorname{Min}\{4,2,5,3,1,3,2,3,2,3,4,4,5,2,3,5,3,4,4,5,3,5,5,4,4\}}{2}=\frac{1}{4}=0,5 \\
& \mathrm{r} 15.1=\frac{\operatorname{Min}\{4,2,5,3,1,3,2,3,2,3,4,4,5,2,3,5,3,4,4,5,3,5,5,4,4\}}{3}=\frac{1}{3}=0,33 \\
& \mathrm{r} 16.1=\frac{\operatorname{Min}\{4,2,5,3,1,3,2,3,2,3,4,4,5,2,3,5,3,4,4,5,3,5,5,4,4\}}{5}=\frac{1}{5}=0,2 \\
& \mathrm{r} 17.2=\frac{\operatorname{Min}\{4,2,5,3,1,3,2,3,2,3,4,4,5,2,3,5,3,4,4,5,3,5,5,4,4\}}{3}=\frac{1}{3}=0,33 \\
& \mathrm{r} 18.2=\frac{\operatorname{Min}\{4,2,5,3,1,3,2,3,2,3,4,4,5,2,3,5,3,4,4,5,3,5,5,4,4\}}{4}=\frac{1}{4}=0,25 \\
& \mathrm{r} 19.2=\frac{\operatorname{Min}\{4,2,5,3,1,3,2,3,2,3,4,4,5,2,3,5,3,4,4,5,3,5,5,4,4\}}{4}=\frac{1}{4}=0,25 \\
& \mathrm{r} 20.2=\frac{\operatorname{Min}\{4,2,5,3,1,3,2,3,2,3,4,4,5,2,3,5,3,4,4,5,3,5,5,4,4\}}{5}=\frac{1}{5}=0,2 \\
& \mathrm{r} 21.2=\frac{\operatorname{Min}\{4,2,5,3,1,3,2,3,2,3,4,4,5,2,3,5,3,4,4,5,3,5,5,4,4\}}{3}=\frac{1}{3}=0,33 \\
& \mathrm{r} 22.2=\frac{\operatorname{Min}\{4,2,5,3,1,3,2,3,2,3,4,4,5,2,3,5,3,4,4,5,3,5,5,4,4\}}{5}=\frac{1}{5}=0,2 \\
& \mathrm{r} 23.2=\frac{\operatorname{Min}\{4,2,5,3,1,3,2,3,2,3,4,4,5,2,3,5,3,4,4,5,3,5,5,4,4\}}{5}=\frac{1}{5}=0,2 \\
& \mathrm{r} 24.2=\frac{\operatorname{Min}\{4,2,5,3,1,3,2,3,2,3,4,4,5,2,3,5,3,4,4,5,3,5,5,4,4\}}{4}=\frac{1}{4}=0,25 \\
& \mathrm{r} 25.2=\frac{\operatorname{Min}\{4,2,5,3,1,3,2,3,2,3,4,4,5,2,3,5,3,4,4,5,3,5,5,4,4\}}{4}=\frac{1}{4}=0,25
\end{aligned}
$$

r1.5 sampai dengan r14.5 adalah nilai normalisasi pada baris pertama kolom ke lima yang digunakan. Dari dimana untuk pencahariannya $\mathrm{MinX}_{\mathrm{ij}}$ adalah nilai minimal kolom $\mathrm{K} 5$ nilai minimalnya adalah ' 1 '. Maka setiap baris dari setiap kriteria dibagi dengan $\mathrm{X}_{\mathrm{ij}}$ adalah nilai kriteria dari kolom K5 menjadi penyebut dari nilai kolom K5.

$$
\begin{aligned}
& r 1.5=\frac{\operatorname{Min}\{1,4,5,4,4,4,2,5,4,2,4,2,5,1,1,5,3,2,5,5,2,5,4,5,1\}}{1}=\frac{1}{1}=1 \\
& r 2.5=\frac{\operatorname{Min}\{1,4,5,4,4,4,2,5,4,2,4,2,5,1,1,5,3,2,5,5,2,5,4,5,1\}}{4}=\frac{1}{4}=0,25 \\
& r 3.5=\frac{\operatorname{Min}\{1,4,5,4,4,4,2,5,4,2,4,2,5,1,1,5,3,2,5,5,2,5,4,5,1\}}{5}=\frac{1}{5}=0,2 \\
& r 4.5=\frac{\operatorname{Min}\{1,4,5,4,4,4,2,5,4,2,4,2,5,1,1,5,3,2,5,5,2,5,4,5,1\}}{4}=\frac{1}{4}=0,25 \\
& r 5.5=\frac{\operatorname{Min}\{1,4,5,4,4,4,2,5,4,2,4,2,5,1,1,5,3,2,5,5,2,5,4,5,1\}}{4}=\frac{1}{4}=0,25 \\
& r 6.5=\frac{\operatorname{Min}\{1,4,5,4,4,4,2,5,4,2,4,2,5,1,1,5,3,2,5,5,2,5,4,5,1\}}{4}=\frac{1}{4}=0,25 \\
& r 7.5=\frac{\operatorname{Min}\{1,4,5,4,4,4,2,5,4,2,4,2,5,1,1,5,3,2,5,5,2,5,4,5,1\}}{2}=\frac{1}{2}=0,5 \\
& r 8.5=\frac{\operatorname{Min}\{1,4,5,4,4,4,2,5,4,2,4,2,5,1,1,5,3,2,5,5,2,5,4,5,1\}}{5}=\frac{1}{5}=0,2
\end{aligned}
$$




$$
\begin{aligned}
& r 9.5=\frac{\operatorname{Min}\{1,4,5,4,4,4,2,5,4,2,4,2,5,1,1,5,3,2,5,5,2,5,4,5,1\}}{4}=\frac{1}{4}=0,25 \\
& r 10.5=\frac{\operatorname{Min}\{1,4,5,4,4,4,2,5,4,2,4,2,5,1,1,5,3,2,5,5,2,5,4,5,1\}}{2}=\frac{1}{2}=0,5 \\
& r 11.5=\frac{\operatorname{Min}\{1,4,5,4,4,4,2,5,4,2,4,2,5,1,1,5,3,2,5,5,2,5,4,5,1\}}{4}=\frac{1}{4}=0,25 \\
& r 12.5=\frac{\operatorname{Min}\{1,4,5,4,4,4,2,5,4,2,4,2,5,1,1,5,3,2,5,5,2,5,4,5,1\}}{2}=\frac{1}{2}=0,5 \\
& r 13.5=\frac{\operatorname{Min}\{1,4,5,4,4,4,2,5,4,2,4,2,5,1,1,5,3,2,5,5,2,5,4,5,1\}}{5}=\frac{1}{5}=0,2 \\
& r 14.5=\frac{\operatorname{Min}\{1,4,5,4,4,4,2,5,4,2,4,2,5,1,1,5,3,2,5,5,2,5,4,5,1\}}{1}=\frac{1}{1}=1 \\
& r 15.5=\frac{\operatorname{Min}\{1,4,5,4,4,4,2,5,4,2,4,2,5,1,1,5,3,2,5,5,2,5,4,5,1\}}{1}=\frac{1}{1}=1 \\
& r 16.5=\frac{\operatorname{Min}\{1,4,5,4,4,4,2,5,4,2,4,2,5,1,1,5,3,2,5,5,2,5,4,5,1\}}{5}=\frac{1}{5}=0,2 \\
& r 17.5=\frac{\operatorname{Min}\{1,4,5,4,4,4,2,5,4,2,4,2,5,1,1,5,3,2,5,5,2,5,4,5,1\}}{3}=\frac{1}{3}=0,33 \\
& r 18.5=\frac{\operatorname{Min}\{1,4,5,4,4,4,2,5,4,2,4,2,5,1,1,5,3,2,5,5,2,5,4,5,1\}}{2}=\frac{1}{2}=0,5 \\
& r 19.5=\frac{\operatorname{Min}\{1,4,5,4,4,4,2,5,4,2,4,2,5,1,1,5,3,2,5,5,2,5,4,5,1\}}{5}=\frac{1}{5}=0,2 \\
& r 20.5=\frac{\operatorname{Min}\{1,4,5,4,4,4,2,5,4,2,4,2,5,1,1,5,3,2,5,5,2,5,4,5,1\}}{5}=\frac{1}{5}=0,2 \\
& r 21.5=\frac{\operatorname{Min}\{1,4,5,4,4,4,2,5,4,2,4,2,5,1,1,5,3,2,5,5,2,5,4,5,1\}}{2}=\frac{1}{2}=0,5 \\
& r 22.5=\frac{\operatorname{Min}\{1,4,5,4,4,4,2,5,4,2,4,2,5,1,1,5,3,2,5,5,2,5,4,5,1\}}{5}=\frac{1}{5}=0,2 \\
& r 23.5=\frac{\operatorname{Min}\{1,4,5,4,4,4,2,5,4,2,4,2,5,1,1,5,3,2,5,5,2,5,4,5,1\}}{4}=\frac{1}{4}=0,25 \\
& r 24.5=\frac{\operatorname{Min}\{1,4,5,4,4,4,2,5,4,2,4,2,5,1,1,5,3,2,5,5,2,5,4,5,1\}}{5}=\frac{1}{5}=0,2 \\
& r 25.5=\frac{\operatorname{Min}\{1,4,5,4,4,4,2,5,4,2,4,2,5,1,1,5,3,2,5,5,2,5,4,5,1\}}{1}=\frac{1}{1}=1
\end{aligned}
$$

e. Membuat matrik kinerja ternormalisasi

Berikut merupakan hasil dari perhitungan didapat dari hasil pengurutan normalisasi dari setiap normalisasi setiap nilai alternatif pada kriteria yang telah alternatif yaitu: ditentukan. $\mathrm{R}$ adalah nilai matriks ternormalisasi yang

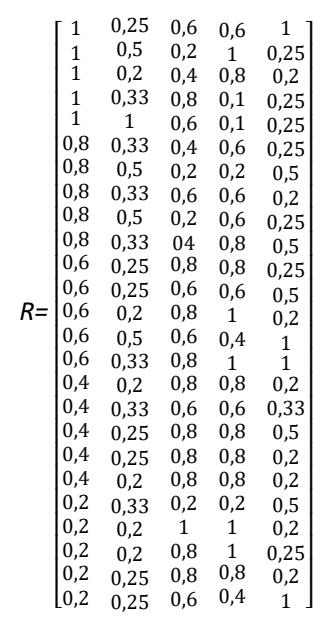


f. Menghitung nilai bobot preferensi pada setiap alternatif (Vi)

Berikut merupakan perhitungan untuk menentukan nilai bobot preferensi dari setiap atlernatif yang digunakan V1 adalah bobot preferensi dimana W1

adalah nilai bobot dari setiap kriteria di kali dengan $r 1.1$ adalah nilai pada setiap alternatif kriteria baris pertama kolom pertama

$$
\begin{aligned}
& \mathrm{V} 1=\left(\mathrm{W}_{1} * \mathrm{r}_{11}\right)+\left(\mathrm{W}_{2} * \mathrm{r}_{12}\right)+\left(\mathrm{W}_{3} * \mathrm{r}_{13}\right)+\left(\mathrm{W}_{4} * \mathrm{r}_{14}\right)+\left(\mathrm{W}_{5} * \mathrm{r}_{15}\right) \\
& =(0.3 * 1)+(0,25 * 0,25)+(0,2 * 0,6)+\left(0,15^{*} 0,6\right)+(0,1 * 1) \\
& =0,3+0,06+0,12+0,9+0,1=0,67 \\
& \mathrm{~V} 2=\left(\mathrm{W}_{1} * \mathrm{r}_{21}\right)+\left(\mathrm{W}_{2} * \mathrm{r}_{22}\right)+\left(\mathrm{W}_{3} * \mathrm{r}_{23}\right)+\left(\mathrm{W}_{4} * \mathrm{r}_{24}\right)+\left(\mathrm{W}_{5} * \mathrm{r}_{25}\right) \\
& =\left(0.3^{*} 1\right)+\left(0,25^{*} 0,5\right)+\left(0,2^{*} 0,2\right)+\left(0,15^{*} 1\right)+\left(0,1^{*} 0,25\right) \\
& =0,3+0,13+0,04+0,15+0,3=0,64 \\
& \text { V3 }=\left(\mathrm{W}_{1} * \mathrm{r}_{31}\right)+\left(\mathrm{W}_{2} * \mathrm{r}_{32}\right)+\left(\mathrm{W}_{3} * \mathrm{r}_{33}\right)+\left(\mathrm{W}_{4} * \mathrm{r}_{34}\right)+\left(\mathrm{W}_{5} * \mathrm{r}_{35}\right) \\
& =(0.3 * 1)+\left(0,25^{*} 0,2\right)+(0,2 * 0,4)+\left(0,15^{*} 0,8\right)+(0,1 * 0,2) \\
& =0,3+0,05+0,08+0,12+0,02=0,57 \\
& \mathrm{~V} 4=\left(\mathrm{W}_{1} * \mathrm{r}_{41}\right)+\left(\mathrm{W}_{2} * \mathrm{r}_{42}\right)+\left(\mathrm{W}_{3} * \mathrm{r}_{43}\right)+\left(\mathrm{W}_{4} * \mathrm{r}_{44}\right)+\left(\mathrm{W}_{5} * \mathrm{r}_{45}\right) \\
& =\left(0.3^{*} 1\right)+\left(0,25^{*} 0,33\right)+(0,2 * 0,8)+\left(0,15^{*} 1\right)+(0,1 * 0,25) \\
& =0,3+0,08+0,16+0,15+0,03=0,72 \\
& \mathrm{~V} 5=\left(\mathrm{W}_{1} * \mathrm{r}_{51}\right)+\left(\mathrm{W}_{2} * \mathrm{r}_{52}\right)+\left(\mathrm{W}_{3} * \mathrm{r}_{53}\right)+\left(\mathrm{W}_{4} * \mathrm{r}_{54}\right)+\left(\mathrm{W}_{5} * \mathrm{r}_{55}\right) \\
& =\left(0.3^{*} 1\right)+\left(0,25^{*} 0,1\right)+(0,2 * 0,6)+\left(0,15^{*} 1\right)+(0,1 * 0,25) \\
& =0,3+0,25+0,12+0,15+0,03=0,85 \\
& \mathrm{~V} 6=\left(\mathrm{W}_{1} * \mathrm{r}_{61}\right)+\left(\mathrm{W}_{2} * \mathrm{r}_{62}\right)+\left(\mathrm{W}_{3} * \mathrm{r}_{63}\right)+\left(\mathrm{W}_{4} * \mathrm{r}_{64}\right)+\left(\mathrm{W}_{5} * \mathrm{r}_{65}\right) \\
& =\left(0.3^{*} 0,8\right)+\left(0,25^{*} 0,33\right)+\left(0,2^{*} 0,4\right)+\left(0,15^{*} 0,6\right)+\left(0,1^{*} 0,25\right) \\
& =0,24+0,08+0,08+0,09+0,03=0,52 \\
& \mathrm{~V} 7=\left(\mathrm{W}_{1} * \mathrm{r}_{71}\right)+\left(\mathrm{W}_{2} * \mathrm{r}_{72}\right)+\left(\mathrm{W}_{3} * \mathrm{r}_{73}\right)+\left(\mathrm{W}_{4} * \mathrm{r}_{74}\right)+\left(\mathrm{W}_{5} * \mathrm{r}_{75}\right) \\
& =\left(0.3^{*} 0,8\right)+\left(0,25^{*} 0,33\right)+\left(0,2^{*} 0,2\right)+\left(0,15^{*} 0,2\right)+\left(0,1^{*} 0,5\right) \\
& =0,24+0,13+0,04+0,03+0,05=0,49 \\
& \mathrm{~V} 8=\left(\mathrm{W}_{1} * \mathrm{r}_{81}\right)+\left(\mathrm{W}_{2} * \mathrm{r}_{82}\right)+\left(\mathrm{W}_{3} * \mathrm{r}_{83}\right)+\left(\mathrm{W}_{4} * \mathrm{r}_{84}\right)+\left(\mathrm{W}_{5} * \mathrm{r}_{85}\right) \\
& =\left(0.3^{*} 0,8\right)+\left(0,25^{*} 0,33\right)+\left(0,2^{*} 0,6\right)+\left(0,15^{*} 0,6\right)+\left(0,1^{*} 0,2\right) \\
& =0,24+0,08+0,12+0,09+0,02=0,55 \\
& \mathrm{~V} 9=\left(\mathrm{W}_{1} * \mathrm{r}_{91}\right)+\left(\mathrm{W}_{2} * \mathrm{r}_{92}\right)+\left(\mathrm{W}_{3} * \mathrm{r}_{93}\right)+\left(\mathrm{W}_{4} * \mathrm{r}_{94}\right)+\left(\mathrm{W}_{5} * \mathrm{r}_{95}\right) \\
& =\left(0.3^{*} 0,8\right)+\left(0,25^{*} 0,5\right)+\left(0,2^{*} 0,2\right)+\left(0,15^{*} 0,6\right)+(0,1 * 25) \\
& =0,24+0,13+0,04+0,09+0,03=0,52 \\
& \mathrm{~V} 10=\left(\mathrm{W}_{1} * \mathrm{r}_{10.1}\right)+\left(\mathrm{W}_{2} * \mathrm{r}_{10.2}\right)+\left(\mathrm{W}_{3} * \mathrm{r}_{10.3}\right)+\left(\mathrm{W}_{4} * \mathrm{r}_{10.4}\right)+\left(\mathrm{W}_{5} * \mathrm{r}_{10.5}\right) \\
& =\left(0.3^{*} 0,8\right)+(0,25 * 0,33)+(0,2 * 0,4)+(0,15 * 0,8)+(0,1 * 0,5) \\
& =0,24+0,08+0,08+0,12+0,05=0,57 \\
& \mathrm{~V} 11=\left(\mathrm{W}_{1} * \mathrm{r}_{11.1}\right)+\left(\mathrm{W}_{2} * \mathrm{r}_{11.2}\right)+\left(\mathrm{W}_{3} * \mathrm{r}_{11.3}\right)+\left(\mathrm{W}_{4} * \mathrm{r}_{11.4}\right)+\left(\mathrm{W}_{5} * \mathrm{r}_{11.5}\right) \\
& =\left(0.3^{*} 0,6\right)+\left(0,25^{*} 0,25\right)+\left(0,2^{*} 0,8\right)+\left(0,15^{*} 0,8\right)+\left(0,1^{*} 0,25\right) \\
& =0,18+0,06+0,16+0,12+0,03=0,55 \\
& \mathrm{~V} 12=\left(\mathrm{W}_{1} * \mathrm{r}_{12.1}\right)+\left(\mathrm{W}_{2} * \mathrm{r}_{12.2}\right)+\left(\mathrm{W}_{3} * \mathrm{r}_{12.3}\right)+\left(\mathrm{W}_{4} * \mathrm{r}_{12.4}\right)+\left(\mathrm{W}_{5} * \mathrm{r}_{12.5}\right) \\
& =\left(0.3^{*} 0,6\right)+\left(0,25^{*} 0,25\right)+\left(0,2^{*} 0,6\right)+\left(0,15^{*} 0,6\right)+\left(0,1^{*} 0,5\right) \\
& =0,18+0,06+0,12+0,9+0,05=0,50 \\
& \mathrm{~V} 13=\left(\mathrm{W}_{1} * \mathrm{r}_{13.1}\right)+\left(\mathrm{W}_{2} * \mathrm{r}_{13.2}\right)+\left(\mathrm{W}_{3} * \mathrm{r}_{13.3}\right)+\left(\mathrm{W}_{4} * \mathrm{r}_{13.4}\right)+\left(\mathrm{W}_{5} * \mathrm{r}_{13.5}\right) \\
& =\left(0.3^{*} 0,6\right)+\left(0,25^{*} 0,2\right)+\left(0,2^{*} 0,8\right)+\left(0,15^{*} 1\right)+\left(0,1^{*} 0,2\right) \\
& =0,18+0,05+0,16+0,15+0,02=0,56 \\
& \mathrm{~V} 14=\left(\mathrm{W}_{1} * \mathrm{r}_{14.1}\right)+\left(\mathrm{W}_{2} * \mathrm{r}_{14.2}\right)+\left(\mathrm{W}_{3} * \mathrm{r}_{14.3}\right)+\left(\mathrm{W}_{4} * \mathrm{r}_{14.4}\right)+\left(\mathrm{W}_{5} * \mathrm{r}_{14.5}\right) \\
& =\left(0.3^{*} 0,6\right)+\left(0,25^{*} 0,5\right)+\left(0,2^{*} 0,6\right)+\left(0,15^{*} 0,4\right)+\left(0,1^{*} 1\right) \\
& =0,18+0,13+0,12+0,06+0,1=0,59 \\
& \mathrm{~V} 15=\left(\mathrm{W}_{1} * \mathrm{r}_{15.1}\right)+\left(\mathrm{W}_{2} * \mathrm{r}_{15.2}\right)+\left(\mathrm{W}_{3} * \mathrm{r}_{15.3}\right)+\left(\mathrm{W}_{4} * \mathrm{r}_{15.4}\right)+\left(\mathrm{W}_{5} * \mathrm{r}_{15.5}\right)
\end{aligned}
$$




$$
\begin{aligned}
& =\left(0.3^{*} 0,6\right)+\left(0,25^{*} 0,33\right)+\left(0,2^{*} 0,8\right)+\left(0,15^{*} 1\right)+\left(0,1^{*} 1\right) \\
& =0,18+0,08+0,16+0,15+0,1=0,67 \\
& \mathrm{~V} 16=\left(\mathrm{W}_{1} * \mathrm{r}_{16.1}\right)+\left(\mathrm{W}_{2} * \mathrm{r}_{16.2}\right)+\left(\mathrm{W}_{3} * \mathrm{r}_{16.3}\right)+\left(\mathrm{W}_{4} * \mathrm{r}_{16.4}\right)+\left(\mathrm{W}_{5} * \mathrm{r}_{16.5}\right) \\
& =\left(0.3^{*} 0,4\right)+\left(0,25^{*} 0,2\right)+\left(0,2^{*} 0,8\right)+\left(0,15^{*} 0,8\right)+(0,1 * 0,2) \\
& =0,12+0,05+0,16+0,12+0,02=0,47 \\
& \mathrm{~V} 17=\left(\mathrm{W}_{1} * \mathrm{r}_{17.1}\right)+\left(\mathrm{W}_{2} * \mathrm{r}_{17.2}\right)+\left(\mathrm{W}_{3} * \mathrm{r}_{17.3}\right)+\left(\mathrm{W}_{4} * \mathrm{r}_{17.4}\right)+\left(\mathrm{W}_{5} * \mathrm{r}_{17.5}\right) \\
& =(0.3 * 0,4)+(0,25 * 033)+(0,2 * 0,6)+(0,15 * 0,6)+(0,1 * 0,33) \\
& =0,12+0,08+0,12+0,09+0,03=0,45 \\
& \mathrm{~V} 18=\left(\mathrm{W}_{1} * \mathrm{r}_{18.1}\right)+\left(\mathrm{W}_{2} * \mathrm{r}_{18.2}\right)+\left(\mathrm{W}_{3} * \mathrm{r}_{18.3}\right)+\left(\mathrm{W}_{4} * \mathrm{r}_{18.4}\right)+\left(\mathrm{W}_{5} * \mathrm{r}_{18.5}\right) \\
& =\left(0.3^{*} 0,4\right)+\left(0,25^{*} 0,25\right)+\left(0,2^{*} 0,8\right)+\left(0,15^{*} 0,8\right)+(0,1 * 0,5) \\
& =0,12+0,06+0,16+0,12+0,05=0,51 \\
& \mathrm{~V} 19=\left(\mathrm{W}_{1} * \mathrm{r}_{19.1}\right)+\left(\mathrm{W}_{2} * \mathrm{r}_{19.2}\right)+\left(\mathrm{W}_{3} * \mathrm{r}_{19.3}\right)+\left(\mathrm{W}_{4} * \mathrm{r}_{19.4}\right)+\left(\mathrm{W}_{5} * \mathrm{r}_{19.5}\right) \\
& =\left(0.3^{*} 0,4\right)+\left(0,25^{*} 0,25\right)+\left(0,2^{*} 0,8\right)+\left(0,15^{*} 0,8\right)+\left(0,1^{*} 0,2\right) \\
& =0,12+0,06+0,16+0,12+0,02=0,48 \\
& \mathrm{~V} 20=\left(\mathrm{W}_{1} * \mathrm{r}_{20.1}\right)+\left(\mathrm{W}_{2} * \mathrm{r}_{20.2}\right)+\left(\mathrm{W}_{3} * \mathrm{r}_{20.3}\right)+\left(\mathrm{W}_{4} * \mathrm{r}_{20.4}\right)+\left(\mathrm{W}_{5} * \mathrm{r}_{20.5}\right) \\
& =\left(0.3^{*} 0,4\right)+\left(0,25^{*} 0,2\right)+(0,2 * 0,8)+\left(0,15^{*} 0,8\right)+(0,1 * 0,2) \\
& =0,12+0,05+0,16+0,12+0,02=0,47 \\
& \mathrm{~V} 21=\left(\mathrm{W}_{1} * \mathrm{r}_{21.1}\right)+\left(\mathrm{W}_{2} * \mathrm{r}_{21.2}\right)+\left(\mathrm{W}_{3} * \mathrm{r}_{21.3}\right)+\left(\mathrm{W}_{4} * \mathrm{r}_{21.4}\right)+\left(\mathrm{W}_{5} * \mathrm{r}_{21.5}\right) \\
& =(0.3 * 0,2)+(0,25 * 0,33)+(0,2 * 0,2)+\left(0,15^{*} 0,2\right)+(0,1 * 0,5) \\
& =0,06+0,08+0,04+0,03+0,05=0,26 \\
& \mathrm{~V} 22=\left(\mathrm{W}_{1} * \mathrm{r}_{22.1}\right)+\left(\mathrm{W}_{2} * \mathrm{r}_{22.2}\right)+\left(\mathrm{W}_{3} * \mathrm{r}_{22.3}\right)+\left(\mathrm{W}_{4} * \mathrm{r}_{22.4}\right)+\left(\mathrm{W}_{5} * \mathrm{r}_{22.5}\right) \\
& =(0.3 * 0,2)+\left(0,25^{*} 0,2\right)+(0,2 * 1)+\left(0,15^{*} 1\right)+(0,1 * 0,2) \\
& =0,06+0,05+0,2+0,15+0,02=0,48 \\
& \mathrm{~V} 23=\left(\mathrm{W}_{1} * \mathrm{r}_{23.1}\right)+\left(\mathrm{W}_{2} * \mathrm{r}_{23.2}\right)+\left(\mathrm{W}_{3} * \mathrm{r}_{23.3}\right)+\left(\mathrm{W}_{4} * \mathrm{r}_{23.4}\right)+\left(\mathrm{W}_{5} * \mathrm{r}_{23.5}\right) \\
& =\left(0.3^{*} 0,2\right)+\left(0,25^{*} 0,2\right)+(0,2 * 0,8)+\left(0,15^{*} 1\right)+(0,1 * 0,25) \\
& =0,06+0,05+0,16+0,15+0,03=0,45 \\
& \mathrm{~V} 24=\left(\mathrm{W}_{1} * \mathrm{r}_{24.1}\right)+\left(\mathrm{W}_{2} * \mathrm{r}_{24.2}\right)+\left(\mathrm{W}_{3} * \mathrm{r}_{24.3}\right)+\left(\mathrm{W}_{4} * \mathrm{r}_{24.4}\right)+\left(\mathrm{W}_{5} * \mathrm{r}_{24.5}\right) \\
& =(0.3 * 2)+(0,25 * 0,25)+(0,2 * 0,8)+(0,15 * 0,8)+(0,1 * 0,2) \\
& =0,06+0,06+0,16+0,12+0,02=0,42 \\
& \mathrm{~V} 25=\left(\mathrm{W}_{1} * \mathrm{r}_{25.1}\right)+\left(\mathrm{W}_{2} * \mathrm{r}_{25.2}\right)+\left(\mathrm{W}_{3} * \mathrm{r}_{25.3}\right)+\left(\mathrm{W}_{4} * \mathrm{r}_{25.4}\right)+\left(\mathrm{W}_{5} * \mathrm{r}_{25.5}\right) \\
& =\left(\left(0.3^{*} 0,2\right)+\left(0,25^{*} 0,25\right)+\left(0,2^{*} 0,6\right)+\left(0,15^{*} 0,4\right)+\left(0,1^{*} 1\right)\right. \\
& =0,06+0,06+0,12+0,06+0,1=0,40
\end{aligned}
$$

g. Melakukan Perangkingan

Berikut merupakan langkah terakhir yang dilakukan yaitu pengurutan nilai yang didapat setelah perhitungan preferensi sehingga mendapatkan nilai rangking terbesar

1 sampai 25 serta muncul beberapa rekomendasi dari toko tanaman hias yang dibutuhkan pelanggan pada Tabel 9. 
Tabel 9. Hasil Perangkingan dari Metode SAW

\begin{tabular}{|c|c|c|c|c|c|}
\hline Nama Tanaman & $\begin{array}{r}\text { Nilai } \\
\text { Bobot } \\
\text { Preferensi } \\
(\mathrm{Vi})\end{array}$ & Rangking & & Rekomendasi Toko & \\
\hline $\begin{array}{l}\text { Philodendron Imperal } \\
\text { Red Cardinal }\end{array}$ & 0,57 & 4 & Taman Bunga Chealsea & Rumah Anggrek Gulip & Dahlia Nursey \\
\hline $\begin{array}{l}\text { Philodendron Prince } \\
\text { Orange }\end{array}$ & 0,64 & 5 & Dahlia Nursey & $\begin{array}{l}\text { Pusat Bunga } \\
\text { Wonoharjo }\end{array}$ & Linda Florist \\
\hline $\begin{array}{l}\text { Philodendron Lemon } \\
\text { Lime }\end{array}$ & 0,57 & 8 & Dahlia Nursey & $\begin{array}{l}\text { Pusat Bunga } \\
\text { Wonoharjo }\end{array}$ & Linda Florist \\
\hline Philodendron Milano & 0,72 & 2 & Taman Bunga Chealsea & Rumah Anggrek Gulip & Dahlia Nursey \\
\hline $\begin{array}{l}\text { Philodendron Congo } \\
\text { Rojo }\end{array}$ & 0,85 & 1 & Taman Bunga Chealsea & Rumah Anggrek Gulip & Dahlia Nursey \\
\hline Monstera Deleciosa & 0,52 & 13 & Rumah Anggrek Gulip & Taman Bunga Celsea & $\begin{array}{l}\text { Pusat Bunga } \\
\text { Wonoharjo }\end{array}$ \\
\hline Monstera Adausonil & 0,49 & 16 & Linda Florist & Dahlia Nursey & Taman Bunga Chelsea \\
\hline Monstera Borsigiana & 0,55 & 10 & Rumah Anggrek Gulip & Taman Bunga Celsea & $\begin{array}{l}\text { Pusat Bunga } \\
\text { Wonoharjo }\end{array}$ \\
\hline Monstera Dubia & 0,52 & 12 & Rumah Anggrek Gulip & Taman Bunga Celsea & $\begin{array}{l}\text { Pusat Bunga } \\
\text { Wonoharjo }\end{array}$ \\
\hline Monstera Variegata & 0,57 & 7 & Dahlia Nursey & $\begin{array}{l}\text { Pusat Bunga } \\
\text { Wonoharjo }\end{array}$ & Linda Florist \\
\hline Aglonema Claudia & 0,55 & 11 & Rumah Anggrek Gulip & Taman Bunga Celsea & $\begin{array}{l}\text { Pusat Bunga } \\
\text { Wonoharjo }\end{array}$ \\
\hline Aglonema Red Ruby & 0,50 & 15 & Linda Florist & Dahlia Nursey & Taman Bunga Chelsea \\
\hline Aglonema Lipstik & 0,56 & 9 & Dahlia Nursey & $\begin{array}{l}\text { Pusat Bunga } \\
\text { Wonoharjo }\end{array}$ & Linda Florist \\
\hline $\begin{array}{l}\text { Aglonema Red } \\
\text { Sumatra }\end{array}$ & 0,59 & 6 & Dahlia Nursey & $\begin{array}{l}\text { Pusat Bunga } \\
\text { Wonoharjo }\end{array}$ & Linda Florist \\
\hline $\begin{array}{l}\text { Aglonema Pictum } \\
\text { Tricolor }\end{array}$ & 0,67 & 3 & Taman Bunga Chealsea & Rumah Anggrek Gulip & Dahlia Nursey \\
\hline Caladium Tikus & 0,47 & 19 & Linda Florist & Dahlia Nursey & Taman Bunga Chelsea \\
\hline Caladium Tengkoral & 0,45 & 21 & $\begin{array}{l}\text { Pusat Bunga } \\
\text { Wonoharjo }\end{array}$ & Linda Florist & Rumah Anggrek Gulip \\
\hline Caladium Wayang & 0,51 & 14 & Rumah Anggrek Gulip & Taman Bunga Celsea & $\begin{array}{l}\text { Pusat Bunga } \\
\text { Wonoharjo }\end{array}$ \\
\hline Caladium Baret Merah & 0,48 & 17 & Linda Florist & Dahlia Nursey & Taman Bunga Chelsea \\
\hline $\begin{array}{l}\text { Caladium Kuping } \\
\text { Kelinci }\end{array}$ & 0,47 & 19 & Linda Florist & Dahlia Nursey & Taman Bunga Chelsea \\
\hline Anggrek Kuku Macan & 0,26 & 25 & $\begin{array}{l}\text { Pusat Bunga } \\
\text { Wonoharjo }\end{array}$ & Linda Florist & Rumah Anggrek Gulip \\
\hline Anggrek Ekor Tupai & 0,48 & 18 & Linda Florist & Dahlia Nursey & Taman Bunga Chelsea \\
\hline Anggrek Bulan & 0,45 & 22 & $\begin{array}{l}\text { Pusat Bunga } \\
\text { Wonoharjo }\end{array}$ & Linda Florist & Rumah Anggrek Gulip \\
\hline Anggrek Tanah & 0,42 & 23 & $\begin{array}{l}\text { Pusat Bunga } \\
\text { Wonoharjo }\end{array}$ & Linda Florist & Rumah Anggrek Gulip \\
\hline Anggrek Tebu & 0,40 & 24 & $\begin{array}{l}\text { Pusat Bunga } \\
\text { Wonoharjo }\end{array}$ & Linda Florist & Rumah Anggrek Gulip \\
\hline
\end{tabular}

Berdasarkan 25 alternatif pilihan pada tabel perangkingan di atas dari hasil perhitungan preferensi dengan metode SAW didapatkan urutan ke 5 dengan nilai terbesar ke 1 dari tanaman hiasPhilodendron Congo rojo $=0,85$ berada di toko Taman Bunga Chealsea Rumah Anggrek Gulip dan Dahlia Nursey.

\section{Kesimpulan}

Kesimpulan dari hasil penelitian ini adalah dengan adanya teknologi yang sudah terkomputerisasi dapat membantu para petani tanaman hias dalam memberikan informasi yang akurat dan lebih cepat kepada pelangganya. Memberikan kemudahan bagi pelanggan dalam membeli dan melakukan pemesanan tanaman hias tanpa butuh waktu lama. Memudahkan pelanggan dalam menggambil keputusan untuk menentukan tanaman hias mana yang akan dipilih sesuai dengan kriterianya. Sistem pendukung keputusan dalam pemilihan tanaman hias ini telah berhasil diperhitungkan sehingga didapatkan hasil perangkingan untuk mendapatkan rekomendasi toko dari alternatif tanaman hias yang dicari susuai dengan keinginan pelanggan. Sehingga adanya analisis perhitungan dari pemilihan tanaman hias sini menjadi alat bantu yang tepat dalam setiap pengambilan keputusan. 


\section{Ucapan Terima Kasih}

Terima kasih disampaikan atas kesediannya menjadi tempat observasi dan bersedia untuk diwawancarai kepada Bapak/Ibu pemilik toko tanaman hias Kabupaten Tanggamus Provinsi Lampung yaitu Taman Bunga Chealsea, dan Dahlia Nursey yang berada di Jl. Raya Gisting Atas Kecamatan Gisting, Pusat Bunga Wonoharjo di Jl. Wonoharjo Kecamatan Sumberjo, Linda Florist di Jl. Sinar Petir Kecamatan Talang Padang, dan 5) Rumah Anggrek Gulip di Jl. Banjar Negeri Kecamatan Gunung Alip.

\section{Daftar Pustaka}

[1] T. Widyastuti, Teknologi Budidaya Tanaman Hias Agribisnis. 2018.

[2] Erlangga Erlangga and A. Furqon, "Portal e-Brosur Berbasis Modern Advertising Methods Untuk Efektifitas Periklanan Jurusan S1 Sistem Informasi Fakultas Ilmu Komputer , Universitas Bandar Lampung," pp. 20-42, 2014.

[3] E. Erlangga, M. H. Anggraini, F. Ariani, and Y. Aprilinda, "Aplikasi E-Marketing Panglong Kayu Menggunakan Metode Colaborative Filtering," Explor. J. Sist. Inf. dan Telemat., vol. 11, no. 1, pp. 57-66, 2020, doi: 10.36448/jsit.v11i1.1460.

[4] H. Hermanto and N. Izzah, "Sistem Pendukung Keputusan Pemilihan Motor Dengan Metode Simple
Additive Weighting (SAW)," Mat. Dan Pembelajaran, vol. 6, no. 2, p. 184, 2018, doi: $10.33477 /$ mp.v6i2.669.

[5] Turban dan Aronson (2011: 75), "Sistem pendukung keputusan 'Landasan Teori,"” no. 2016, pp. 10-48.

[6] R. W. Kusumadewi, Sri, Sri Hartati, Agus Harjoko, "Fuzzy Multi-Criteria Decision Making," in Furzy MultiCriteria Decision Making, 2005.

[7] 1968 Fishburn, 1967 MacCrimmon, Metode-Metode Penyelesaian Masalah MDAM. .

[8] M. ko. Rochmat Tufiq, S., Sistem Pendukung Keputusan. 2020.

[9] E. Dianasari and T. Baidawi, "Sistem Pendukung Keputusan Penilaian Tanaman Anggrek Pada Ud. Sanjiwani Orchid Menggunakan Metode Simple Additive Weighting," Swabumi, vol. III, no. 1, pp. 16-23, 2015.

[10]E. Vista, B. Dolok, M. Marbun, and T. Informatika, "Penerapan Metode Topsis Pada Sistem Pendukung," vol. 4, no. 1, pp. 49-53, 2020.

[11]A. R. Utami, Solikhun, and Irwan, "Sistem Pendukung Keputusan Pemilihan Jenis Bibit Unggul Kelapa Sawit Dengan Metode Analytic Hierarchy Process (AHP)," Prosiding Seminar Ilmu Komputer dan Teknologi Informasi. 2017.

[12]Sugiyono 2003:11, "Metode penelitian." Metode Penelitian dan Pengembangan:Research and Development. Bandung: Alfabeta. 